\title{
Patenty uprawniające do uprawiania turystyki wodnej na jachtach żaglowych - zagadnienia prawne
}

\section{Wprowadzenie}

Aktem prawnym regulującym warunki uprawiania żeglugi sportowej i rekreacyjnej jest Ustawa z dnia 21 grudnia 2000 r. o żegludze śródlądowej ${ }^{1}$. Stosownie do art. 37a ust. 1 tego aktu prowadzenie statków przeznaczonych do uprawiania sportu lub rekreacji wymaga posiadania odpowiedniej wiedzy i umiejętności z zakresu żeglarstwa oraz przestrzegania zasad bezpieczeństwa przy uprawianiu turystyki wodnej. Przepis ten, w myśl art. 37a ust. 2 pkt 1 u.ż.ś., dotyczy statków przeznaczonych do uprawiania turystyki wodnej - m.in. o napędzie żaglowym (jachtów żaglowych), które moga być wyposażone w pomocniczy napęd mechaniczny.

Zwrócić jednak należy uwagę, że - jak stanowi art. 37a ust. 3 u.ż.ś. uprawianie turystyki wodnej na jachtach żaglowych o długości kadłuba powyżej 7,5 m wymaga co do zasady posiadania dokumentu kwalifikacyjnego wydanego przez właściwy polski związek sportowy². Kwestie charakteru prawnego tego dokumentu oraz procedury jego wydania są przedmiotem rozważań prowadzonych w niniejszym opracowaniu.

${ }^{1}$ Tekst jedn. Dz.U. 2013, poz. 1458 ze zm., dalej „u.ż.ś.”. Zob. art. 1 ust. 3 tej ustawy.

2 Jest on potocznie nazywany "patentem żeglarskim”, co nie jest w pełni prawidłowe ze względu na to, że terminem tym posługuje się w odmiennym znaczeniu u.ż.ś. - zob. np. art. 35 ust. 2-4 tego aktu. Samo delegowanie na polski związek sportowy - Polski Związek Żeglarski - kompetencji do wydawania dokumentów kwalifikacyjnych może być traktowane jako przejaw prywatyzacji wykonywania zadań publicznych - por. S. Biernat, Prywatyzacja zadań publicznych (zarys problematyki), „Państwo i Prawo” 1993, z. 5, s. 6-7. 


\section{Status prawny Polskiego Związku Żeglarskiego}

Należy wskazać, że obecnie „właściwym polskim związkiem sportowym" do wydania dokumentu kwalifikacyjnego, o którym mowa w przepisach u.ż.ś., jest Polski Związek Żeglarski (PZŻ). Należy go zakwalifikować jako polski związek sportowy w rozumieniu Ustawy z dnia 25 czerwca 2010 r. o sporcie ${ }^{3}$. Posiada bowiem wszystkie konieczne do takiej klasyfikacji cechy: jest to związek sportowy o zasięgu ogólnokrajowym, utworzony za zgodą właściwego ministra, działający w jednym sporcie, którego członkami są kluby sportowe oraz któremu ustawa przyznaje monopol w organizowaniu współzawodnictwa sportowego w danym sporcie na terenie Polski i reprezentowania Polski w danym sporcie we współzawodnictwie na arenie międzynarodowej ${ }^{4}$. Można mówić o dwóch aspektach funkcjonowania polskiego związku sportowego: organizacyjno-funkcjonalnym - organizowanie i prowadzenie współzawodnictwa, oraz terytorialnym - polski związek sportowy ma charakter ogólnokrajowy ${ }^{5}$. Oba warunki spełnia Polski Związek Żeglarski.

Polskie związki sportowe należą do podmiotów, do których w sprawach nienormowanych w ustawach odrębnych regulujących ich status stosuje się odpowiednio przepisy Ustawy z dnia 7 kwietnia 1989 r. Prawo o stowarzyszeniach ${ }^{6}$, ze względu na zawarte w art. 7 ust. 3 u.s. odesłanie $^{7}$. Mogą być także kwalifikowane jako odrębny typ osoby prawnej, uregulowany w sposób szczególny w u.s. ${ }^{8}$ Specyficzny charakter polskiego związku sportowego związany jest ze znaczną autonomia, którą mu się przypisuje, posiada bowiem szeroki zakres praw wyłącznych (art. 13, art. 14 ust. 1, art. 15 ust. 1 u.s.) $)^{9}$. W tym kontekście należy zauważyć, że polskie związki sportowe posiadają niekiedy także

${ }^{3}$ Tekst jedn. Dz.U. 2016, poz. 176 ze zm., dalej „u.s.”. Zob. poz. 68 wykazu polskich związków sportowych z dnia 2 VIII 2016 r., opublikowany przez Ministra Sportu i Turystyki: https://d1dmfej9n5lgmh.cloudfront.net/msport/article_attachments/ attachments/96790/original/wykaz_polskich_zwi\%C4\%85zk\%C3\%B3w_sportowych. pdf?1470214436 (dostęp: 19 III 2017).

${ }^{4}$ Zob. M. Badura, H. Basiński, G. Kałużny, M. Wojcieszak, Ustawa o sporcie. Komentarz, Warszawa 2011, s. 98-99.

${ }^{5}$ S. Fundowicz, Prawo sportowe, Warszawa 2013, s. 76.

${ }^{6}$ Tekst jedn. Dz.U. 2015, poz. 1393 ze zm.

7 Por. S. Fundowicz, op. cit., s. 77.

${ }^{8}$ Ibidem.

${ }^{9}$ Ibidem, s. 79. 
kompetencje władcze ${ }^{10}$. Wyrazem tego jest m.in. oparte na art. 37a ust. 7 u.ż.ś. uprawnienie Polskiego Związku Żeglarskiego do wydawania przywołanych w tytule niniejszego opracowania dokumentów poświadczających uprawnienia do prowadzenia jachtów żaglowych określonej wielkości na oznaczonych wodach osobom posiadającym odpowiednią wiedzę i umiejętności z zakresu żeglarstwa oraz spełniającym inne wymagania określone w przepisach Rozporządzenia Ministra Sportu i Turystyki z dnia 9 kwietnia 2013 r. w sprawie uprawiania turystyki wodnej ${ }^{11}$.

Stosownie do art. 37a ust. 8 u.ż.ś. do uzyskania rzeczonego dokumentu niezbędne jest zdanie egzaminu potwierdzającego posiadanie odpowiedniej wiedzy i umiejętności z zakresu żeglarstwa. Egzamin ten przeprowadza Polski Związek Żeglarski lub podmiot upoważniony przez ministra właściwego do spraw kultury fizycznej ${ }^{12}$. Zdanie tego egzaminu jest zatem warunkiem sine qua non ubiegania się przez jednostkę o wydanie patentu.

Za przeprowadzenie egzaminu oraz czynności związanych z wydaniem dokumentu uprawniającego do prowadzenia określonej wielkości jachtów żaglowych na oznaczonych wodach pobiera się opłatę, która stanowi dochód PZŻ (art. 37a ust. 9 i 10 u.ż.ś.). Maksymalną wysokość opłaty określa art. 37 a ust. 11 u.ż.ś., zaś precyzuje $\S 22$ rozporządzenia w sprawie uprawiania turystyki wodnej.

Zaznaczenia wymaga, że to na Polskim Związku Żeglarskim - stosownie do art. 37a ust. 12 u.ż.ś. - ciąży obowiązek prowadzenia ewidencji wydanych dokumentów oraz gromadzenia zaświadczeń potwierdzających zdanie egzaminu, będących podstawą do wydania owych dokumentów patentowych.

Biorąc pod uwagę powyższe regulacje, PZŻ nie może być ujmowany wyłącznie jako byt cywilnoprawny („parastowarzyszeniowy"),

\section{Ibidem.}

${ }^{11}$ Dz.U. 2013, poz. 460, dalej „rozporządzenie w sprawie uprawiania turystyki wodnej” lub "rozporządzenie".

${ }^{12}$ Problematykę upoważnienia podmiotu do przeprowadzania egzaminu, o którym mowa w art. 37a ust. 8 u.ż.ś., reguluje art. 37b u.ż.ś. Nadzór nad przeprowadzaniem egzaminu przez podmiot upoważniony sprawuje minister właściwy do spraw kultury fizycznej (art. 37b ust. 6 u.ż.ś.). W ramach sprawowanego nadzoru minister właściwy do spraw kultury fizycznej ma prawo żądać udostępnienia dokumentów, pisemnych wyjaśnień dotyczących przeprowadzanego egzaminu oraz dokonywać kontroli (art. 37b ust. 7 u.ż.ś.). 
ale - w omawianym kontekście - powinien być traktowany również jako podmiot sprawujacy funkcje o charakterze administracji publicznej ${ }^{13}$. Jest zatem podmiotem administrującym. Wykonuje powierzone mu przez ustawodawcę zadania publiczne, w tym także w stosunku do jednostek niebędących członkami Związku. Warto zaznaczyć, że takie ukształtowanie pozycji PZŻ nie może być uznane za niekonstytucyjne ograniczenie wolności związku sportowego (art. 31 ust. 2 i 3 ustawy zasadniczej $)^{14}$.

\section{Dokumenty kwalifikacyjne potwierdzające posiadanie uprawnień do kierowania jachtami żaglowymi (patenty)}

Dla tytułowej problematyki szczególne znaczenie ma wydane na podstawie art. 37a ust. 15 u.ż.ś. rozporządzenie w sprawie uprawiania turystyki wodnej. Określa ono: wymagania niezbędne do uzyskania dokumentów potwierdzających posiadanie uprawnień, w szczególności dotyczące wiedzy i umiejętności z zakresu żeglarstwa, oraz odpowiadający im zakres uprawnień do prowadzenia jachtów żaglowych albo motorowych; sposób i tryb przeprowadzania egzaminu potwierdzającego posiadanie odpowiedniej wiedzy i umiejętności z zakresu żeglarstwa; wzór zaświadczenia o zdaniu egzaminu; wzory dokumentów potwierdzających posiadanie uprawnień; wysokość opłat za przeprowadzenie egzaminu oraz za czynności związane z wydaniem dokumentu kwalifikacyjnego do uprawiania turystyki wodnej.

Jak wskazuje § 2 ust. 1 rozporządzenia, dokumentami kwalifikacyjnymi potwierdzającymi posiadanie uprawnień do uprawiania turystyki wodnej na jachtach żaglowych o długości kadłuba powyżej 7,5 m są patenty: żeglarza jachtowego, jachtowego sternika morskiego, kapitana jachtowego, a także - przy uwzględnieniu $§ 13$ ust. 1 rozporządzenia sternika motorowodnego, motorowodnego sternika morskiego, kapitana motorowodnego, mechanika motorowodnego. Ich wzór określa załącznik nr 1 do rozporządzenia. Przesłanki uzyskania poszczególnych patentów zostały określone odpowiednio w § 5-11 rozporządzenia. Ich

${ }^{13}$ Por. wyrok Trybunału Konstytucyjnego (TK) z 19 X 2010 r., sygn. P 10/10, „Orzecznictwo Trybunału Konstytucyjnego - Zbiór Urzędowy” 2010, seria A, nr 8, poz. 78, pkt 2.5; A. Gronkiewicz, Organizacja społeczna w ogólnym postępowaniu administracyjnym, Warszawa 2012, s. 123.

14 Por. wyrok TK z 19 X 2010 r., sygn. P 10/10, pkt 5.3. 
analiza wskazuje, że prawodawca wyróżnił trzy, różnie kształtowane w zależności od typu patentu, kategorie kryteriów:

1. wieku,

2. wiedzy i umiejętności,

3. doświadczenia żeglarskiego.

De lege ferenda, mając na względzie konieczność zapewnienia bezpieczeństwa na wodach, należy wysunąć postulat uzupełnienia wymogów do uzyskania patentu o dodatkowe kryterium w postaci posiadania aktualnego orzeczenia lekarskiego o braku przeciwwskazań do kierowania jachtem żaglowym. Można by w tym zakresie odpowiednio stosować przepisy art. 75-81 Ustawy z dnia 5 stycznia 2011 r. o kierujących pojazdami ${ }^{15}$.

Prawodawca ustanowił trzy stopnie patentów uprawniających do prowadzenia jachtów żaglowych: żeglarza jachtowego, jachtowego sternika morskiego, kapitana jachtowego.

Pierwszy z nich - patent żeglarza jachtowego - uprawnia do prowadzenia jachtów żaglowych po wodach śródlądowych, a także jachtów o długości kadłuba do $12 \mathrm{~m}$ po morskich wodach wewnętrznych oraz pozostałych wodach morskich w strefie do 2 mil morskich od brzegu, w porze dziennej. Uzyskać może go osoba, która ukończyła 14. rok życia oraz zdała egzamin z wymaganej wiedzy i umiejętności ( $\$ 5$ rozporządzenia).

Drugi z wymienionych patentów - jachtowego sternika morskiego uprawnia do prowadzenia jachtów żaglowych po wodach śródlądowych oraz jachtów o długości kadłuba do $18 \mathrm{~m}$ po wodach morskich. Może go uzyskać osoba, która ukończyła 18. rok życia, odbyła co najmniej dwa rejsy po wodach morskich w łącznym czasie co najmniej 200 godzin żeglugi, a także zdała egzamin z wymaganej wiedzy i umiejętności ( $\$ 6$ rozporządzenia).

Wreszcie ostatni patent - kapitana jachtowego - uprawnia do prowadzenia wszystkich jachtów żaglowych po wodach śródlądowych i morskich. Aby go uzyskać, należy posiadać patent jachtowego sternika morskiego, a ponadto po uzyskaniu patentu jachtowego sternika morskiego odbyć co najmniej sześć rejsów po wodach morskich w łącznym czasie co najmniej 1200 godzin żeglugi, w tym co najmniej 400 godzin samodzielnego prowadzenia jachtu o długości kadłuba powyżej 7,5 m, oraz odbyć co najmniej jeden rejs powyżej 100 godzin żeglugi

15 Tekst jedn. Dz.U. 2016, poz. 627 ze zm. 
na jachcie o długości kadłuba powyżej $20 \mathrm{~m}$ i jeden rejs powyżej 100 godzin żeglugi po wodach pływowych z zawinięciem do co najmniej dwóch portów pływowych ( $\$ 7$ rozporządzenia).

\section{Charakter prawny patentów w żeglarstwie jachtowym}

Analizy wymaga charakter prawny omawianych dokumentów kwalifikacyjnych, o których mowa w art. 37 a ust. 3 u.ż.ś., a zatem patentów wskazanych w $\S 2$ ust. 1 rozporządzenia w sprawie uprawiania turystyki wodnej. Uznać należy je za oficjalne urzędowe dokumenty państwowe, z mocą dowodu urzędowego (art. 76 \& 2 Ustawy z dnia 14 czerwca $1960 \mathrm{r}$. Kodeks postępowania administracyjnego ${ }^{16}$ ). Sa to miarodajne dla wszystkich organów akty, z którymi przepisy prawa wiążą określone konsekwencje prawne. Dokument kwalifikacyjny sam w sobie nie jest oceną ani nie nadaje uprawnień, lecz poświadcza ich uzyskanie i posiadanie przez imiennie oznaczoną osobę. Stwierdza zatem jej uprawnienie do prowadzenia jachtu żaglowego oznaczonej wielkości na określonych wodach. W tym względzie wykazuje pewne prawdopodobieństwo do certyfikatów, prawa jazdy ${ }^{17}$, świadectw szkolnych ${ }^{18}$, jakkolwiek może być także rozpatrywany w kategoriach swoistego zaświadczenia.

Wypada zaznaczyć, że kierowanie jachtem żaglowym przez osobę nieposiadającą właściwego dokumentu kwalifikacyjnego jest zabronione i - na mocy art. 61 pkt 1 u.ż.ś. - podlega karze grzywny. W tym zakresie należy skądinąd postulować zaostrzenie sankcji karnej, gdyż dolegliwość aktualnej wydaje się w praktyce nieznaczna. Maksymalna grzywna wynosi bowiem pięć tysięcy złotych ${ }^{19}$, a uwzględnić należy, że osobami uprawiającymi turystykę wodną na jachtach żaglowych są nierzadko osoby zamożne, dla których nawet taka kwota nie będzie ekonomicznie odczuwalna.

${ }^{16}$ Tekst jedn. Dz.U. 2016, poz. 23 ze zm., dalej „k.p.a.”.

${ }^{17}$ Por. art. 4 ust. 1 pkt 1 lit. a) ustawy o kierujących pojazdami.

${ }_{18}$ Por. J. Homplewicz, Polskie prawo szkolne. Zagadnienia podstawowe, Warszawa 1984, s. 204-207. Por. postanowienie Naczelnego Sądu Administracyjnego (NSA) z 30 I 2015 r., sygn. I OSK 74/15, Centralna Baza Orzeczeń Sądów Administracyjnych (CBOSA).

${ }^{19}$ Zob. art. 24 § 1 Ustawy z dnia 20 V 1971 r. - Kodeks wykroczeń (tekst jedn. Dz.U. 2015, poz. 1094 ze zm.) w zw. z art. 63 u.ż.ś. 


\section{Sprawa o wydanie patentu w żeglarstwie}

W tym miejscu należy rozważyć fundamentalną dla tytułowego zagadnienia kwestię charakteru prawnego sprawy w przedmiocie uzyskania przez osobę uprawnień, wyrażających się wydaniem przez Polski Związek Żeglarski dokumentu kwalifikacyjnego (patentu) do uprawiania turystyki wodnej na jachtach żaglowych. Uwagi wymaga zatem, czy może być ona zakwalifikowana jako sprawa administracyjna, czy też ma charakter cywilnoprawny.

Sprawa administracyjna jest $\mathrm{w}$ doktrynie definiowana m.in. jako przewidziana $\mathrm{w}$ przepisach materialnego prawa administracyjnego możliwość konkretyzacji wzajemnych uprawnień i obowiązków stron stosunku administracyjnoprawnego, którymi są: organ administracji i indywidualny podmiot niepodporządkowany organizacyjnie temu organowi ${ }^{20}$. T. Kiełkowski ujmuje przedmiotową sprawę jako kwestię istnienia stanu faktycznego, opisanego w hipotezie normy prawnej wymagającej dla uwolnienia swej mocy wiążącej autorytatywnej konkretyzacji dokonanej w formie aktu wydanego przez właściwy organ administrujący ${ }^{21}$.

Na tym tle należy zauważyć, że sprawa potwierdzenia uzyskania uprawnień do prowadzenia jachtów żaglowych (wydania patentu) polega na analizie możliwości konkretyzacji (przewidzianej w przepisach § 5-7 rozporządzenia w sprawie uprawiania turystyki wodnej) przez organ administracji publicznej w znaczeniu funkcjonalnym (PZŻ) tych uprawnień, związanych $z$ uprawianiem turystyki wodnej na jachtach żaglowych, względem indywidualnej osoby. Uprawnienia te wydawane są $\mathrm{w}$ formie deklaratoryjnego aktu wskazanego organu, a potwierdza je dokument kwalifikacyjny. Wnioskodawca nie jest przy tym podległy ani służbowo, ani organizacyjnie Polskiemu Związkowi Żeglarskiemu. Co więcej, nie można mówić w tej relacji o równorzędności stron ${ }^{22}$. To bowiem PZŻ władczo i jednostronnie rozstrzyga, czy danemu wnioskodawcy można wydać patent uprawniający do prowadzenia jachtu żaglowego czy nie. Obywatel pozbawiony jest swobody - bez dokumentu

${ }^{20}$ T. Woś, Pojęcie "sprawy" w przepisach kodeksu postępowania administracyjnego, "Acta Universitatis Wratislaviensis. Prawo" 1990, nr 160, s. 334.

${ }^{21}$ T. Kiełkowski, Sprawa administracyjna, Kraków 2004, s. 35.

${ }^{22}$ Por. wyrok TK z 19 X 2010 r., sygn. P 10/10, pkt 2.2. 
kwalifikacyjnego (patentu) nie może wszak prowadzić jachtu żaglowego o określonych wymiarach i na oznaczonych wodach ${ }^{23}$.

Relacja między jednostką ubiegającą się o uzyskanie uprawnień (patentu) a Polskim Związkiem Żeglarskim jest zatem stosunkiem administracyjnoprawnym, gdyż wykazuje wszelkie jego cechy: nierównorzędność stron, gdzie jedną z nich jest organ upoważniony do władczego i jednostronnego kształtowania sytuacji prawnej podmiotu mu niepodporządkowanego służbowo czy organizacyjnie, relacja regulowana jest przepisami prawa administracyjnego, a wreszcie należy do sfery działania administracji opartej na władztwie państwowym ${ }^{24}$. Konkludując, sprawa wydania patentu uprawniającego do uprawiania turystyki wodnej na jachtach żaglowych jest sprawą administracyjną. Konieczne jest zatem przeanalizowanie trybu jej załatwienia.

\section{Postępowanie egzaminacyjne w celu uzyskania uprawnień żeglarskich}

Postępowanie w sprawie przyznania patentu uprawniającego do uprawiania turystyki wodnej na jachtach żaglowych - dla patentu żeglarza jachtowego lub jachtowego sternika morskiego - jest dwuetapowe, zaś dla patentu kapitana jachtowego - jednoetapowe (brak postępowania egzaminacyjnego).

Pierwszy etap toczy się przed komisją egzaminacyjną, o której mowa w $\S 16$ ust. 1 rozporządzenia w sprawie uprawiania turystyki wodnej. Obejmuje on przystąpienie do egzaminu $z$ wymaganej wiedzy i umiejętności potrzebnych do uzyskania danego patentu. O planowanych terminach egzaminów, w myśl $\S 19$ ust. 4 rozporządzenia, dowiedzieć się można na stronie internetowej Polskiego Związku Żeglarskiego lub podmiotu upoważnionego przez ministra właściwego do spraw kultury fizycznej do przeprowadzenia egzaminu. Warunkiem przystąpienia do egzaminu, stosownie do § 14 rozporządzenia, jest przedstawienie dowodu uiszczenia opłaty egzaminacyjnej oraz spełnienie wymogów niezbędnych do uprawiania turystyki wodnej dla uzyskania patentu, a zatem w przypadku ubiegania się o patent żeglarza jachtowego - ukończenie

${ }^{23}$ Wyrok TK z 19 X 2010 r., sygn. P 10/10, pkt 4.3.

${ }^{24}$ Por. R. Hauser, Pojęcie i znaczenie stosunku administracyjnoprawnego, w: Instytucje prawa administracyjnego, seria System Prawa Administracyjnego, pod red. R. Hausera, Z. Niewiadomskiego, A. Wróbla, t. 1, Warszawa 2010, s. 195-199. 
wieku 14 lat, zaś dla patentu jachtowego sternika morskiego - ukończenie 18 lat życia oraz odbycie co najmniej dwóch rejsów po wodach morskich, w łącznym czasie co najmniej 200 godzin żeglugi.

Komisja egzaminacyjna jest powoływana przez PZŻ albo podmiot upoważniony przez ministra właściwego do spraw kultury fizycznej do przeprowadzenia egzaminu - składa się co najmniej z przewodniczącego oraz sekretarza. Skład komisji może być poszerzony o dodatkowych członków, lecz nie może ona liczyć więcej niż pięć osób (§ 16 rozporządzenia). Przesłanki bezwzględnego wyłączenia osoby od egzaminowania ze względu na relacje z egzaminowanym określa z kolei § 18 rozporządzenia. Wzmacniają one gwarancje bezstronności, równości i sprawiedliwości w procesie egzaminowania.

Egzamin składa się z części teoretycznej i praktycznej - jego przebieg jest uregulowany w $\S 17$ rozporządzenia. Warunkiem zdania egzaminu jest uzyskanie oceny pozytywnej z obu części. Zakres wymagań określa załącznik nr 4 do rozporządzenia.

Część teoretyczna egzaminu na patent żeglarza jachtowego ma formę pisemną i składa się z testu jednokrotnego wyboru z 75 pytaniami przygotowanymi przez komisję na podstawie odpowiadającego właściwemu patentowi zakresu wymagań egzaminacyjnych. Egzaminowany ma 90 minut na udzielenie odpowiedzi. Za pozytywny wynik egzaminu teoretycznego na patent żeglarza jachtowego uważa się uzyskanie 65 prawidłowych odpowiedzi w teście.

Część teoretyczna egzaminu na patent jachtowego sternika morskiego ma również formę pisemną i składa się z testu jednokrotnego wyboru z 75 pytaniami oraz zadania nawigacyjnego, przygotowanych przez komisję na podstawie odpowiadającego właściwemu patentowi zakresu wymagań egzaminacyjnych. Egzaminowany ma 120 minut na udzielenie odpowiedzi oraz rozwiązanie zadania. Za pozytywny wynik egzaminu teoretycznego na patent jachtowego sternika morskiego uważa się uzyskanie 65 prawidłowych odpowiedzi w teście oraz prawidłowe rozwiązanie zadania nawigacyjnego.

Przewodniczący komisji sprawuje ogólny nadzór nad przebiegiem egzaminu teoretycznego; stały dyżur na sali egzaminacyjnej pełni co najmniej jedna osoba ze składu komisji.

Część praktyczna egzaminu obejmuje wykonanie wybranych przez komisję elementów egzaminacyjnych określonych przez komisję indywidualnie dla każdego zdającego na podstawie odpowiadającego właściwemu patentowi zakresu wymagań egzaminacyjnych. W ramach 
części praktycznej są sprawdzane wybrane elementy dotyczące manewrowania jachtem. Za pozytywny wynik egzaminu praktycznego uważa się prawidłowe wykonanie wszystkich elementów wskazanych przez egzaminatora do wykonania, przy czym dopuszcza się jednokrotne powtórzenie źle wykonanego elementu.

Zestawy zadań do wykonania w ramach egzaminu praktycznego i pytań egzaminacyjnych na egzaminie teoretycznym zatwierdza pisemnie przewodniczący komisji, opatrując każdy z nich datą, podpisem i pieczątką imienną. Zadania i pytania egzaminacyjne są przygotowywane, przechowywane i przekazywane w warunkach uniemożliwiających ich nieuprawnione ujawnienie. Zaznaczyć należy przy tym, że przewodniczący, sekretarz i członkowie komisji są obowiązani zachować w tajemnicy tematy egzaminacyjne.

Stosownie do $§ 19$ rozporządzenia z przeprowadzonego egzaminu sporządza się protokół zawierający dane osób egzaminowanych (imiona i nazwiska, miejsca i daty urodzenia, adresy zamieszkania), jak również zwięzły opis przebiegu egzaminu (w tym opis elementów wykonanych podczas części praktycznej), ocenę końcową oraz podpisy wszystkich osób wchodzących w skład komisji. Dokumentację z przeprowadzonych egzaminów prowadzi Polski Związek Żeglarski lub podmiot upoważniony przez ministra właściwego do spraw kultury fizycznej do przeprowadzenia egzaminu.

Przepisy przewidują także procedurę na wypadek niepomyślnego zakończenia pierwszego etapu, a zatem niezdania przez daną osobę egzaminu. W takiej sytuacji, jak stanowi § 20 rozporządzenia, może ona przystapić do egzaminu ponownie, po uiszczeniu wymaganej opłaty, przy czym jest on powtarzany w całości. Z kolei w przypadku nieprzystąpienia do egzaminu w wyznaczonym terminie osoba, która już uiściła należną opłatę, może - zgodnie z § 20 ust. 3 rozporządzenia - przystąpić do egzaminu w innym terminie wyznaczonym przez komisję egzaminacyjną.

Jak była mowa, zdanie egzaminu jest warunkiem sine qua non uruchomienia drugiego etapu, tj. wszczęcia postępowania przed Polskim Związkiem Żeglarskim (jako organem właściwym w sprawie na podstawie art. 37 a ust. 7 u.ż.ś.) o przyznanie osobie uprawnień do uprawiania turystyki wodnej na jachtach żaglowych. Negatywny rezultat egzaminu kończy zatem postępowanie już na pierwszym etapie. Mimo to wynik egzaminu nie stanowi aktu administracyjnego, który mógłby być kwalifikowany jako decyzja administracyjna w rozumieniu k.p.a. Nie jest 
aktem woli. Nie oznacza to jednak, że pierwszy etap kończony jest formą prawnie nieznaną. Przeciwnie, akt określający wynik z egzaminu stanowi tzw. akt wiedzy ${ }^{25}$, zbliżony do opinii o spełnieniu warunków przez daną osobę do uzyskania określonego patentu. Znajduje on wyraz w zaświadczeniu - o zdaniu egzaminu potwierdzającego posiadanie wiedzy i umiejętności z zakresu żeglarstwa - którego wzór określa załącznik nr 3 do rozporządzenia. Stanowi zatem indywidualny akt z zakresu administracji publicznej (w znaczeniu funkcjonalnym) dotyczący uprawnień jednostki wynikających bezpośrednio z przepisu art. 37a ust. 7 u.ż.ś. Procedura jego wydania, jak to wyżej przedstawiono, została wyczerpująco uregulowana w rozporządzeniu.

W tym miejscu spostrzec należy, że powyższy akt - negatywny dla adresata - może podlegać kognicji sądów administracyjnych na podstawie art. $3 \S 2$ pkt 4 Ustawy z dnia 30 sierpnia 2002 r. - Prawo o postępowaniu przed sądami administracyjnymi ${ }^{26}$. Jakkolwiek w praktyce nie był on jeszcze nigdy do tej pory przedmiotem uwagi judykatury, to zauważyć wypada, że sądy administracyjne analizowały już zbliżone przypadki ${ }^{27}$. Wolno zatem zakładać, że ewentualna skarga (np. na bezczynność w wydaniu zaświadczenia o zdaniu egzaminu potwierdzającego posiadanie wiedzy i umiejętności z zakresu żeglarstwa - art. 3 § 2 pkt 8 p.p.s.a.) zostałaby rozpoznana.

\section{Postępowanie w sprawie wydania patentu}

W przypadku pomyślnego zakończenia etapu pierwszego dana osoba składa wniosek do PZŻ o wydanie określonego patentu uprawniającego do prowadzenia jachtów żaglowych. Wniosek ten stanowi żądanie strony w rozumieniu art. $61 \S 1$ k.p.a., a zatem - stosownie do tego

${ }^{25}$ Por. postanowienie NSA z 28 VI 2016 r., sygn. I OSK 1328/16, „Orzecznictwo Sądów Polskich" 2017, nr 4, poz. 37; A. Jakubowski, Glosa do postanowienia Wojewódzkiego Sądu Administracyjnego w Bialymstoku z 14 marca 2013 r., II SA/Bk 1011/12, "Orzecznictwo Sądów Polskich" 2013, nr 9, s. 657.

${ }^{26}$ Tekst jedn. Dz.U. 2016, poz. 718 ze zm., dalej „p.p.s.a.”.

${ }^{27}$ Por. np. postanowienie NSA z 28 VI 2016 r., sygn. I OSK 1328/16, "Orzecznictwo Sądów Polskich" 2017, nr 4, poz. 37; postanowienie Wojewódzkiego Sądu Administracyjnego (WSA) w Białymstoku z 14 III 2013 r., sygn. II SA/Bk 1011/12, "Orzecznictwo Sądów Polskich" 2013, nr 9, poz. 91, z glosą A. Jakubowskiego, op. cit., s. 655-657; K. Ziemski, Glosa do postanowienia WSA w Białymstoku z 21 maja 2008 r., II SA/Bk 22/08, „Orzecznictwo Sądów Polskich” 2009, nr 10, s. 716-718. 
przepisu - wszczyna postępowanie administracyjne, regulowane przepisami wskazanego Kodeksu. Podkreślić wypada za Trybunałem Konstytucyjnym, że poglądy odmawiające uznania polskiego związku sportowego za organ administracji publicznej w znaczeniu funkcjonalnym, wykluczające stosowanie w postępowaniu przed nim przepisów k.p.a. - jednoznacznie utraciły swoją aktualnośćc ${ }^{28}$. Zarazem niedopuszczalny byłby w państwie prawnym (art. 2 Konstytucji Rzeczypospolitej Polskiej ${ }^{29}$ ) stan, w którym organ rozstrzygałby o prawach i obowiązkach jednostki, zagadnieniach dotyczących jej interesu, w sposób dowolny, nieregulowany prawem, poza istniejąca procedurą i w formach jej nieznanych ${ }^{30}$.

Zaznaczyć należy, że osoba, która przeszła pierwszy etap, ma interes prawny w rozumieniu art. 28 k.p.a., oparty bezpośrednio na przepisach $\S 5$ ust. 1 (patent żeglarza jachtowego), § 6 ust. 1 (patent jachtowego sternika morskiego) albo $\S 7$ ust. 1 (patent kapitana jachtowego) rozporządzenia w sprawie uprawiania turystyki wodnej, aby móc wszcząć postępowanie i być jego stroną. Oczywiście, postępowanie wszczyna tylko wniosek o wydanie patentu kompletny, odpowiadający przepisom prawa, a więc posiadający elementy określone w art. $63 \S 2$ k.p.a. oraz $\mathrm{w} \S 4$ rozporządzenia. Powinien on zatem zawierać imię i nazwisko, miejsce i datę urodzenia, adres zamieszkania oraz podpis wnioskodawcy, jak również określenie rodzaju wnioskowanego patentu, zdjęcie o wymiarach $3,5 \times 4,5 \mathrm{~cm}$ oraz datę. Do wniosku należy załączyć: zaświadczenie o zdaniu egzaminu, którego wzór określa załącznik nr 3 do rozporządzenia - w przypadku gdy egzamin ten jest wymagany; dokumenty potwierdzające spełnienie wymagań stażowych, w szczególności pozytywne opinie $z$ odbytych rejsów wystawione przez kapitana jachtu, karty rejsu lub - w przypadku rejsów prowadzonych samodzielnie - inne dokumenty potwierdzone przez armatora jachtu; wreszcie pisemną zgodę rodziców lub opiekunów prawnych na uprawianie turystyki wodnej - w przypadku osoby małoletniej.

Jeżeli wniosek zawiera braki formalne, wówczas Polski Związek Żeglarski - stosownie do dyrektywy wyrażonej w art. 64 § 2 k.p.a. - zobowiązany jest wezwać osobę wnoszącą wniosek do usunięcia braków w terminie co najmniej 7 dni z pouczeniem, że nieusunięcie tych braków

\footnotetext{
${ }^{28}$ Zob. wyrok TK z 19 X 2010 r., sygn. P 10/10, pkt 2.5 i 4.3.

${ }^{29}$ Konstytucja Rzeczypospolitej Polskiej z dnia 2 IV 1997 r. (Dz.U. Nr 78, poz. 483 ze zm.), dalej „Konstytucja RP”.

${ }^{30}$ Por. wyrok Sądu Najwyższego z 18 XI 1993 r., sygn. III ARN 49/93, „Orzecznictwo Sądu Najwyższego - Izby Cywilnej i Pracy" 1994, nr 9, poz. 181.
} 
spowoduje pozostawienie podania bez rozpoznania. Od wskazanego obowiązku PZŻ zwolniony jest tylko w sytuacji określonej w art. 64 § 1 k.p.a., a zatem wtedy, gdy nie ma możliwości ustalenia adresu osoby wnoszącej wniosek. W takiej sytuacji może bowiem pozostawić go bez rozpoznania. Podkreślić jednak należy, że gdy uczyni to w sposób nieuzasadniony, wówczas naraża się na zarzut bezczynności ${ }^{31}$.

Wszczęte postępowanie w sprawie wydania patentu (dokumentu kwalifikacyjnego) potwierdzającego uprawnienia danej osoby do prowadzenia jachtów żaglowych musi być prowadzone zgodnie z przepisami k.p.a., w tym jego zasadami. Oznacza to, że Polski Związek Żeglarski musi działać na podstawie przepisów prawa (art. 6 k.p.a.), stojąc $\mathrm{w}$ toku postępowania na straży praworządności, z urzędu lub na wniosek stron podejmując wszelkie czynności niezbędne do dokładnego wyjaśnienia stanu faktycznego oraz do załatwienia sprawy, mając przy tym na względzie interes społeczny i słuszny interes obywateli (art. 7 k.p.a.). Kolejno, postępowanie prowadzone przez PZŻ powinno budzić zaufanie jego uczestnika do działania administracji, w tym poczucie bezstronności i równego potraktowania (art. 8 k.p.a.). Stosownie do art. 9 k.p.a. związek ten jest obowiązany do należytego i wyczerpującego informowania strony o okolicznościach faktycznych i prawnych, które moga mieć wpływ na ustalenie jej praw i obowiązków będących przedmiotem postępowania administracyjnego. Ma on zatem czuwać nad tym, aby strona uczestnicząca w postępowaniu nie poniosła szkody z powodu nieznajomości prawa i - w tym celu - jest zobowiązany udzielać jej niezbędnych wyjaśnień i wskazówek. Wreszcie, w myśl art. 11 k.p.a., Polski Związek Żeglarski powinien wyjaśniać stronie zasadność przesłanek, jakimi kieruje się przy załatwieniu sprawy. W tym kontekście, stosownie do art. 79a § 1 k.p.a., PZŻ obowiązany jest zwłaszcza poinformować stronę o przesłankach, które są od niej zależne, a których nie spełniła dotychczas, co może determinować dla niej negatywne załatwienie jej sprawy.

Na uwagę zasługuje obowiązek Polskiego Związku Żeglarskiego, aby wyczerpująco zebrać i rozpatrzeć cały materiał dowodowy (art. 77 $\S 1$ k.p.a.), a następnie na jego podstawie oceniać udowodnienie okoliczności istotnych dla załatwienia sprawy (art. 80 k.p.a.), określonych w $\S 5$ ust. $1, \S 6$ ust. 1 lub $\S 7$ ust. 1 rozporządzenia.

${ }^{31}$ Zob. uchwała NSA z 3 IX 2013 r., sygn. I OPS 2/13, "Orzecznictwo Naczelnego Sądu Administracyjnego i Wojewódzkich Sądów Administracyjnych” 2014, nr 1, poz. 2. 
Co szczególnie ważne, przepisy k.p.a. determinują także terminowość postępowania w sprawie wydania patentu uprawniającego do uprawiania turystyki wodnej na jachtach żaglowych. Zgodnie z zasada wyrażoną w art. $12 \S 1$ k.p.a. Polski Związek Żeglarski powinien działać w omawianej sprawie wnikliwie i szybko, posługując się możliwie najprostszymi środkami prowadzącymi do jej załatwienia. Należy przy tym zaznaczyć, że z reguły przedmiotowe sprawy nie wymagają od organu zebrania dowodów, informacji lub wyjaśnień, a zatem - jak nakazuje to art. $12 \S 2$ i art. $35 \S 1$ k.p.a. - powinny być załatwione niezwłocznie $^{32}$. Należą bowiem do kategorii, o której mowa w art. $35 \S 2$ k.p.a. Niezależnie od tego, stosownie do art. 35 \& 3 k.p.a., termin wydania patentu żeglarskiego wynosi nie więcej niż miesiąc od dnia złożenia kompletnego, odpowiadającego przepisom prawa wniosku. Nie sposób bowiem uznać, że materia ta tworzy sprawę szczególnie skomplikowaną, wymagającą dwóch miesięcy na jej załatwienie. Brak jest przy tym w przepisach powszechnie obowiązujących norm, które w myśl art. 35 $\S 4$ k.p.a. odmiennie regulowałyby termin załatwienia sprawy.

W tym miejscu warto zwrócić uwagę na środki prawne dyscyplinujące Polski Związek Żeglarski do terminowego załatwienia sprawy. Po pierwsze, należy do nich ponaglenie na niezałatwienie sprawy w terminie, o którym mowa w art. 37 § 1 k.p.a., składane do organu wyższego stopnia. Stosownie do art. 17 pkt 4 k.p.a. organami wyższego stopnia w rozumieniu k.p.a. są w stosunku do organów organizacji społecznych odpowiednie organy wyższego stopnia tych organizacji, a w razie ich braku - organ państwowy sprawujący nadzór nad ich działalnością. Zgodnie $\mathrm{z}$ art. 16 ust. 1 u.s. nadzór nad działalnością polskich związków sportowych sprawuje minister właściwy do spraw kultury fizycznej. A zatem minister właściwy do spraw kultury fizycznej jest właściwy do rozpatrzenia ponaglenia na niezałatwienie sprawy $\mathrm{w}$ terminie przez PZŻ. W myśl art. 37 § 6 k.p.a., uznając ponaglenie za uzasadnione, minister wyda postanowienie, w którym zobowiąże związek do załatwienia niezakończonej sprawy, wyznaczając termin do jej załatwienia, jak też zarządzi wyjaśnienie przyczyn i ustalenie osób winnych niezałatwienia sprawy w terminie, a w razie potrzeby także podjęcie środków zapobiegających naruszaniu terminów załatwiania spraw w przyszłości. Jednocześnie minister stwierdzi, czy niezałatwienie sprawy w terminie miało

${ }^{32}$ Ze względu na tę właściwość warte rozważenia byłoby wprost określenie w przepisach, że sprawa wydania omawianego patentu podlega rozpatrzeniu w trybie uproszczonym, stosownie do art. $163 \mathrm{~b} \S 1$ k.p.a. 
miejsce z rażącym naruszeniem prawa. Pamiętać należy, że pracownik organu administracji publicznej, który z nieuzasadnionych przyczyn nie załatwił sprawy w terminie lub prowadził postępowanie dłużej, niż było to niezbędne do załatwienia sprawy, podlega odpowiedzialności porządkowej lub dyscyplinarnej albo innej odpowiedzialności przewidzianej w przepisach prawa (art. 38 k.p.a.).

Po złożeniu ponaglenia strona może ponadto wnieść skargę do wojewódzkiego sądu administracyjnego na bezczynność lub przewlekłość postępowania w jej sprawie, opierając się na art. $3 \S 2$ pkt $8 \mathrm{w}$ zw. $\mathrm{z}$ art. $52 \S 1$ i art. $53 \S 2$ b p.p.s.a. Sąd administracyjny, stosownie do art. $149 \S 1$ p.p.s.a., uwzględniając skargę na bezczynność lub przewlekłe prowadzenie postępowania:

a) zobowiąże Polski Związek Żeglarski do załatwienia, w określonym terminie, sprawy wydania patentu albo

b) zobowiąże Polski Związek Żeglarski do stwierdzenia albo uznania uprawnienia lub obowiązku wynikających z przepisów prawa bądź

c) stwierdzi, że Polski Związek Żeglarski dopuścił się bezczynności lub przewlekłego prowadzenia postępowania.

Jednocześnie na podstawie art. 149 § 1a p.p.s.a. sąd stwierdzi, czy bezczynność lub przewlekłe prowadzenie postępowania miały miejsce z rażącym naruszeniem prawa. Co więcej, na podstawie art. 149 \& 2 p.p.s.a. władny jest on także wymierzyć Polskiemu Związkowi Żeglarskiemu grzywnę oraz przyznać od niego na rzecz skarżącego oznaczoną sumę pieniężną.

Postępowanie w przedmiocie wydania patentu uprawniającego do uprawiania turystyki wodnej na jachtach żaglowych jest załatwiane co do istoty $\mathrm{w}$ formie decyzji administracyjnej, co wynika $\mathrm{z}$ art. 1 pkt $2 \mathrm{w}$ zw. $z$ art. 104 k.p.a. Akt kończący in meriti to postępowanie ma wszystkie elementy materialne decyzji administracyjnej: pochodzi od organu administracji w znaczeniu funkcjonalnym i w sposób władczy rozstrzyga w sprawie indywidualnej o prawach osoby niepodlegającej temu organowi służbowo czy organizacyjnie ${ }^{33}$. Stosownie do przepisów § 5-7 rozporządzenia, posługujących się imperatywnym zwrotem "uzyskuje”, jest to decyzja deklaratoryjna, związana, niepozostawiona uznaniu organu.

${ }^{33}$ Zob. postanowienie NSA z 1 VII 2015 r., sygn. I OSK 1644/15, CBOSA; wyrok NSA z 21 II 1994 r., sygn. I SAB 54/93, „Orzecznictwo Sądów Polskich” 1995, nr 11, poz. 221, z glosą aprobującą B. Adamiak i J. Borkowskiego, „Orzecznictwo Sądów Polskich” 1995, nr 11, s. 495-498. 
Z powyższych względów nie sposób zaakceptować postanowienia WSA w Warszawie z 25 września 2015 r. ${ }^{34}$, w którego uzasadnieniu sąd wskazał, że z istniejących "uregulowań nie wynika, aby Związek w czynnościach o wydanie dokumentu określającego uprawnienia do prowadzenia określonej wielkości jachtów żaglowych albo motorowych na określonych wodach posiadał uprawnienia do wydania decyzji, a postępowanie przed nim toczyło się według zasad k.p.a.". Wyraził on również pogląd, że dokument kwalifikacyjny, o którym mowa w art. 37a ust. 3 u.ż.ś., nie ma charakteru władczego (rozstrzygającego), ale jedynie potwierdzający spełnienie warunków określonych w art. 37a ust. 1 tego aktu. Twierdzenia te nie odpowiadaja prawdzie. Uprawnienie danej osoby do uprawiania turystyki wodnej na jachtach żaglowych nie wynika przecież bezpośrednio z mocy prawa, lecz uzależnione jest od potwierdzenia spełnienia przez nią wymagań, co następuje w prawnie opisanej procedurze. To akt Polskiego Związku Żeglarskiego decyduje o tym, czy dana osoba będzie mogła korzystać z tych uprawnień czy nie. Nie sposób zatem twierdzić, że akt ten nie ma charakteru władczego, skoro załatwia on jednostronnie konkretną sprawę indywidualną co do istoty. Kwestię tę wyjaśniono wyżej. Przypomnieć też należy, że prawna forma działania administracji nie zawsze wynika wprost z przepisów prawa $^{35}$, wymaga nierzadko ustalenia w drodze wykładni pozajęzykowej, której jednak WSA w Warszawie nie przeprowadził. Pogląd tego sądu zaprezentowany $\mathrm{w}$ cytowanym orzeczeniu prowadziłby $\mathrm{w}$ istocie do zakwestionowania wydawania przez organy decyzji o charakterze deklaratoryjnym. Musi to budzić sprzeciw i odrzucenie stanowiska zawartego w przywołanym judykacie. Warto też dodać, że postanowienie to nie koresponduje z orzecznictwem Naczelnego Sądu Administracyjnego, który w pełni analogiczne akty - tyle że wydawane przez organy administracji państwowej - traktuje jednoznacznie jako decyzje administracyjne ${ }^{36}$.

W zdecydowanej większości przypadków wynik postępowania jest korzystny dla jego strony, a zatem rozstrzygnięcie zostanie jej zakomunikowane przez sam fakt doręczenia dokumentu kwalifikacyjnego, o którym mowa w art. 37a ust. 3 u.ż.ś. Takie załatwienie sprawy jest

${ }^{34}$ Postanowienie WSA w Warszawie z 25 IX 2015 r., sygn. VI SA/Wa 1862/15, CBOSA.

${ }^{35}$ Por. J. Borkowski, Glosa do wyroku NSA z 14 czerwca 1985 r., III SA 327/85, "Orzecznictwo Sądów Polskich i Komisji Arbitrażowych" 1987, nr 7-8, s. 325-326.

${ }^{36}$ Zob. zapadły w sprawie odmowy wydania dyplomu kapitana wyrok NSA z 14 IV 2016 r., sygn. II GSK 2342/14, CBOSA. O charakterze aktu nie decyduje zaś podmiot, który go wydaje, lecz charakter czynności prawnej. 
dopuszczalne w świetle art. 14 § 2 k.p.a. w zw. z art. $107 \S 4$ k.p.a., powinno jednak zostać utrwalone $\mathrm{w}$ aktach sprawy $\mathrm{w}$ formie stosownej adnotacji (np. podpisu na zwrotnym potwierdzeniu odbioru koperty z patentem). Co więcej, przedstawiona mniej sformalizowana ścieżka sprzyja szybszemu załatwieniu sprawy (por. art. 12 k.p.a.).

Odmienna sytuacja ma miejsce wówczas, gdy Polski Związek Żeglarski odmawia wydania patentu. W takiej sytuacji zobowiązany jest on wydać na piśmie decyzję administracyjną ${ }^{37}$, która będzie zawierać wszystkie elementy wskazane w art. $107 \S 1$ k.p.a., a zatem oznaczenie Polskiego Związku Żeglarskiego, datę wydania, oznaczenie strony, powołanie podstawy prawnej, rozstrzygnięcie (tzw. osnowę), uzasadnienie faktyczne i prawne, pouczenie, czy i w jakim trybie służy od niej odwołanie, podpis z podaniem imienia i nazwiska oraz stanowiska służbowego osoby upoważnionej do wydania decyzji lub, jeżeli decyzja wydana została $\mathrm{w}$ formie dokumentu elektronicznego, powinna być opatrzona bezpiecznym podpisem elektronicznym weryfikowanym za pomocą ważnego kwalifikowanego certyfikatu. Ze względu na zasady ogólne k.p.a. oraz konieczność zapewnienia stronie efektywnego prawa do procesu, w tym do kontroli sądowej, szczególne znaczenie ma uzasadnienie decyzji ${ }^{38}$. Zgodnie $\mathrm{z}$ art. $107 \S 3$ k.p.a. uzasadnienie faktyczne powinno przede wszystkim zawierać wskazanie faktów, które organ uznał za udowodnione, dowodów, na których się oparł, oraz przyczyn, z powodu których innym dowodom odmówił wiarygodności i mocy dowodowej, zaś uzasadnienie prawne - wyjaśnienie podstawy prawnej decyzji, z przytoczeniem przepisów prawa. Uzasadnienie decyzji musi być skonkretyzowane do warunków danej sprawy.

Od decyzji strona ma prawo wnieść odwołanie (art. $127 \S 1$ i 2 k.p.a.) do organu wyższego stopnia - ministra właściwego do spraw kultury fizycznej (art. 17 pkt 4 k.p.a. w zw. z art. 16 ust. 1 u.s.) - w terminie 14 dni od dnia jej doręczenia (art. $129 \S 2$ k.p.a.). Z kolei od decyzji ministra wydanej na skutek tego odwołania, stosownie do art. $3 \S 2$ pkt 1 p.p.s.a., stronie przysługuje skarga do wojewódzkiego sądu administracyjnego, wnoszona za pośrednictwem organu (art. $54 \S 1$ p.p.s.a.) w terminie 30 dni od dnia doręczenia decyzji (art. 53 § 1 p.p.s.a.).

${ }^{37}$ Por. uchwała NSA z 16 XII 2013 r., sygn. II GPS 2/13, „Orzecznictwo Naczelnego Sądu Administracyjnego i Wojewódzkich Sądów Administracyjnych" 2014, nr 6, poz. 88.

${ }^{38} \mathrm{O}$ uzasadnieniu zob. szerzej: J. Zimmermann, Znaczenie uzasadnienia rozstrzygnięcia organu administracji publicznej dla orzecznictwa sądowoadministracyjnego, „Zeszyty Naukowe Sądownictwa Administracyjnego" 2010, nr 5-6, s. 511-523. 
Na koniec należy zaznaczyć, że także w trybie k.p.a. następować będzie ewentualne wznowienie postępowania administracyjnego w sprawie wydania patentu potwierdzającego uprawnienia do prowadzenia jachtu (art. 145-145b k.p.a.) lub stwierdzenie nieważności decyzji wydanej w tym przedmiocie (art. $156 \S 1$ k.p.a.). Dotyczy to np. sytuacji, gdy patent został wydany na skutek przestępstwa (art. $145 \S 1$ pkt 2 k.p.a.) albo gdy wyszyły na jaw istotne dla sprawy nowe okoliczności faktyczne lub nowe dowody istniejące $\mathrm{w}$ dniu wydania decyzji, nieznane organowi, który wydał decyzję (art. $145 \S 1$ pkt 5 k.p.a.). Także na podstawie przepisów k.p.a. oraz decyzji administracyjnej następować będzie zatrzymanie dokumentu kwalifikacyjnego (patentu) kierownika jachtu (art. 11 ust. 2 u.ż.ś.), jak również zawieszenie lub pozbawienie uprawnień $\mathrm{z}$ tego dokumentu wynikających (art. 56 pkt 2-4 u.ż.ś.).

\section{Podsumowanie}

Stosowanie w przedmiotowej sprawie trybu określonego w k.p.a. należy ocenić pozytywnie niezależnie od tego, że sam Polski Związek Żeglarski nie jest klasycznym podmiotem administracji publicznej, co - jak już wspominano - nie przeszkadza traktować go jako organ administracyjny w ujęciu funkcjonalnym (art. 1 pkt 2 k.p.a.). Jak bowiem zauważa M. Stahl, podmiot niepubliczny, wykonując zadania administracji publicznej, pozostaje podmiotem prywatnym, ale w sensie funkcjonalnym ma charakter podmiotu administrującego i staje się - w tym jedynie zakresie - takim podmiotem, elementem funkcjonalnie rozumianego systemu administracji publicznej. Konsekwencją opisanego usytuowania jest obowiązek działania na podstawie takich samych zasad, na jakich działaja podmioty publiczne, stosowania tych samych procedur, a zwłaszcza uwzględniania w tych działaniach interesu publicznego. Wykonywanie zadań administracji publicznej nie musi przy tym stanowić ani wyłącznego, ani nawet głównego zakresu działania podmiotu prywatnego ${ }^{39}$.

Przekazanie Polskiemu Związkowi Żeglarskiemu kompetencji do nadawania uprawnień żeglarskich stanowi ustawowe zlecenie zadań

${ }^{39}$ M. Stahl, Niepubliczne podmioty administrujace, w: Podmioty administrujace, seria System Prawa Administracyjnego, pod red. R. Hausera, Z. Niewiadomskiego, A. Wróbla, t. 6, Warszawa 2011, s. 536. 
i funkcji o charakterze publicznym ${ }^{40}$. Można je odczytywać jako zabieg wzmacniający społeczeństwo obywatelskie ${ }^{41}$. Przekazanie zadań, a w szczególności funkcji administracji publicznej, wywiera wpływ na pozycje jednostki i wymaga prawnych gwarancji ochrony jej interesów. Jeśli zlecenie funkcji władczych wiąże się z podejmowaniem decyzji administracyjnych, jak w omawianej sytuacji, to ochronę gwarantują przepisy procedury administracyjnej (k.p.a.), zapewniona jest wtedy także ochrona sądowoadministracyjna ${ }^{42}$. Jak podkreśla M. Stahl, jeśli zważyć, że zlecanie zadań i funkcji rozumiane jest także jako jedna z form uspołeczniania administracji i realizacji zasady dobra wspólnego (art. 1 Konstytucji RP), stosowana ze względu na ważne racje merytoryczne i społeczne, to zapewnienie gwarancji ochrony jednostki staje się niezbędnym elementem konstrukcji prawnej zlecania zadań i funkcji administracji publicznej ${ }^{43}$. Wyrazem tego jest właśnie stosowanie przepisów k.p.a. w postępowaniu przed Polskim Związkiem Żeglarskim w przedmiocie potwierdzenia uprawnień osoby do uprawiania turystyki wodnej na jachtach żaglowych (wydania patentu: żeglarza jachtowego, jachtowego sternika morskiego albo kapitana jachtowego).

\section{SAILING LICENCES ALLOWING TOURISM ON SAILING YACHTS - LEGAL ISSUES}

\section{Sum mary}

The article considers the issue of sailing licences which include: a sailor licence, a steersman licence and a captain licence. The legal character of sailing licences and the procedure in which they are issued is analysed. The judicial control of sailing licences is also considered.

The granting of a sailing licence is an act confirming that a person indicated therein has certain qualifications required for sailing. The legal character of the licence is similar to an administrative certificate. Granting the sailing licence can be conditional upon passing a formal examination by a person requesting the licence to be issued. The examination itself is regarded as an administrative act in law.

The study proves that the Polish Sailing Association performs a function of a public administration unit issuing sailing licences. This means that it acts as an administrative body in a functional dimension.

\footnotetext{
${ }^{40}$ Szerzej o pojęciu zlecenia zadań i funkcji zob. ibidem, s. 537-542.

${ }^{41}$ Por. ibidem, s. 551.

42 Ibidem, s. 541-542.

${ }^{43}$ Ibidem, s. 542.
} 
The sailing licence is granted in the form of a declarative decision issued by the Polish Sailing Association. The proceeding for issuing such a decision is an administrative proceedings governed by the Code of Administrative Proceedings. The actions of the Polish Sailing Association as well as its failure to act are controlled by administrative courts.

Keywords: sailing licences - Polish Sailing Association - water sports - administrative law - sports law 